\title{
Effect of N-acetylcysteine on Hepatic Ischemia- reperfusion Injury in Normal and Steatotic Rats
}

\author{
Nahid M. Tahoon *, Ahmed A. Abdalfattah * \\ Department of Physiology*, Faculty of Medicine, Tanta University
}

\begin{abstract}
Background: Liver ischemia-reperfusion (I/R) injury occurs during major liver surgery, transplantation or following haemorrhagic shock with subsequent fluid resuscitation. Liver steatosis is a risk factor in liver transplantation and liver resection. Aim: This study was undertaken to evaluate the effect of $N$-acetylcysteine (NAC) on hepatic I/R injury in both normal and steatotic rat livers. Material and methods: 48 male wistar rats, divided into 2 equal groups, steatosis was induced in one of them by high cholesterol diet for 8 weeks. Each of these 2 groups was subdivided into 3 subgroups; control, I/R, I/R+ NAC groups. At the end of experiment, liver enzymes, inflammatory, lipid peroxidation and oxidative parameters were assessed and histopathological examination of liver samples was done to prove the incidence of steatosis. Results: NAC produced significant reduction in liver enzymes, inflammatory, lipid peroxidation parameters and significant increase in antioxidant parameters in both normal and steatotic rats. Conclusion: NAC may be considered as a promising therapeutic candidate for chemoprevention of hepatic $I / R$ injury through its antioxidant, anti-inflammatory, antifibrotic, antiapoptic and antisteatotic effects in either normal or steatotic livers.
\end{abstract}

Keywords: Ischemia-reperfusion, $N$-acetylcysteine , steatosis.

\section{INTRODUCTION}

Liver ischemia-reperfusion (I/R) injury occurs during major liver surgery, transplantation or following hemorrhagic shock and subsequent fluid resuscitation ${ }^{(1)}$. The pathophysiology of $\mathrm{I} / \mathrm{R}$ injury involves the activation of many metabolic pathways and release of mediators that induce liver injury ${ }^{(2)}$.

There is growing evidence that there are two distinct phases of liver injury after warm $I / R$, the early phase (up to $2 \mathrm{hr}$ post-reperfusion) is characterized by activation of kupffer cell-induced oxidative stress ${ }^{(3)}$. In the late phase (4-24 hr post-reperfusion), the main event is accumulation of activated neutrophils and the production of free radicals and proteases $^{(4)}$. One of the most important components of intracellular antioxidant system is glutathione (GSH), a powerful active radical scavenger that is depleted during severe liver $\mathrm{I} / \mathrm{R}$ injury ${ }^{(5)}$. Exogenous GSH cannot enter the cell, so its intracellular buildup requires cysteine, which is its major constituent, to be supplied from outside. Nacetylcysteine (NAC) is an exogenous GSH precursor ${ }^{(6)}$.

In the last thirty years, hepatic steatosis has been well-decumented as most common chronic liver disease in 
general population ${ }^{(7)}$. Either as isolated or cooperative factors; mitochondrial dysfunction, inflammatory cytokines, free fatty acids, endotoxin, microvascular injury and oxidative stress may all be involved in the pathogenesis of ischemia-reperfusion injury ${ }^{(8)}$. In this study, we assessed the effect of NAC on hepatic I/R injury in both normal and steatotic rat livers.

\section{MATERIAL \& METHODS}

Drugs:

1. N-acetylecysteine (Sigma Co., USA).

2. Cholesterol powder (Winlab Company for Pharmaceuticals).

\section{Animal model for $I / R$ :}

Anaesthesia was induced by intramuscular injection of $0.5 \mathrm{ml} / \mathrm{kg}$ body weight fentanyl-fluanisone. Rats then underwent inhalation anaesthesia with isoflurane $(0.5-2 \%)$.Rectal temperature was maintained at 35$37^{\circ} \mathrm{C}$ with warming blanket. A median laparotomy was performed, the ligaments of the liver were cut, all structures in the portal triad (hepatic artery, portal vein and bile duct) of the median and left lobes of the liver were clamped by using a traumatic microvascular clip and the abdomen was closed. After one hour, a second labarotomy was performed and the clip was removed, and the animals were kept alive for $4 \mathrm{hr}$ after reperfusion.

\section{Experimental groups and protocol:}

Forty eight adult male wistar rats that weighed 200-250 gm were maintained in a daily $12 \mathrm{hr}$ light-dark cycle, room temperature and free access to tap water. Steatosis was induced by feeding the animal with a high cholesterol $(2 \%)$ diet for 8 weeks $^{(3)}$ in twenty four rats. The other twenty four rats were fed a standard balanced diet. Each group was furtherly subdivided into 3 subgroups, each of 8 rats as follow:

1. Group IA (Control group): Shamoperated without $\mathrm{I} / \mathrm{R}$ and received vehicle $(20 \mathrm{ml}$ of $5 \%$ dextrose over30min then continued at rate of $10 \mathrm{ml} / \mathrm{h}$ over 4 hours).

2. Group IIA (I/R group): I/R was performed and received vehicle (20ml of $5 \%$ dextrose over $30 \mathrm{~min}$ before reperfusion and continued at rate of $10 \mathrm{ml} / \mathrm{h}$ over 4 hours reperfusion period).

3. Group IIIA (NAC + I/R group): $\mathrm{I} / \mathrm{R}$ was performed and received NAC $(150 \mathrm{mg} / \mathrm{kg}$ body weight in 20 $\mathrm{ml}$ of $5 \%$ dextrose was infused intravenously through the tail vein over $30 \mathrm{~min}$ before reperfusion and maintained at $10 \mathrm{ml} / \mathrm{kg} / \mathrm{hr}$ in $5 \%$ dextrose during the $4 \mathrm{~h}$ reperfusion period $^{(4)}$.

4. Group IB (Steatotic control): Sham-operated without $\mathrm{I} / \mathrm{R}$ and received vehicle as in group IA.

5. Group IIB (Steatotic I/R): I/R was performed and received vehicle as in group IIA.

6. Group IIIB (NAC + steatotic I/R): $\mathrm{I} / \mathrm{R}$ was performed and received NAC in the same dose as group IIIA.

At the end of the experiment, arterial blood samples were collected into EDTA-coated tubes and serum was separated and stored until analysis. Liver was quickly excised for analysis and histopathology. Then animals were killed by exanguination. Methods: 
Determination of serum alanine aminotransferase $(\mathrm{ALT})^{(\mathbf{9})}$, alkaline phosphatase $(\mathrm{AP})^{(\mathbf{1 0})}$ and lactate dehdrogenase $\mathrm{LDH}^{(11)}$ by enzymatic colorimeric methods, and are expressed as U/L.

Tumour necrosis factor- $\alpha$ (TNF$\alpha$ ) was estimated by Commercial Sandwich ELISA kits for rats according to manufacturer's instructions (Biosource, Intenational, Camarillo, California, USA) ${ }^{(\mathbf{1 2})}$, and expressed as $\mathrm{Pg} / \mathrm{ml}$.

Malondialdehyde (MDA) was measured by thiobarbituric acid method (13) and is expressed as $\mu \mathrm{mol} / \mathrm{ml}$.

Reduced glutathione (GSH) by fluorometric method of Hissin and Hifi ${ }^{(14)}$, and is expressed as $\mathrm{nmol} / \mathrm{mg}$ protein.

Measurement of Catalase ${ }^{(15)}$ by peroxide substrate method and is expressed as U/gm tissue.

\section{Histopathological examination:}

Sections of liver were taken, kept in formalin and fixed in paraffin blocks. Then cut by microtome and stained by hematoxylin and eosin to prove the incidence of steatosis.

\section{Statistical analysis:}

Data were expressed as mean + SD. Statistical difference involving multiple group comparisons were determined by one way ANOVA, followed by scheffe $(\mathrm{F})$ test. The least significant different mean values $(\mathrm{P}<$ 0.05) was accepted to denote significant difference. This is done by using SPSS computer program version 16.

\section{RESULTS}

As shown in table $(1,2)$ and Fig. $(1,2,3,4,5$ and 6$)$ :

Steatosis produced significant increase in TNF- $\alpha$ and MDA and significant reduction in reduced GSH $(\mathrm{P}<0.05)$ when compared to the normal control group. Steatosis and inflammatory infiltration were also evident by histopathological examination (Fig.5,6).

$\mathrm{I} / \mathrm{R}$ either in normal control or steatotic rats produced significant increase in liver enzymes (ALT, AP and LDH), TNF- $\alpha$ and MDA $(\mathrm{P}<$ $0.05)$ and significant reduction in reduced GSH and catalase $(\mathrm{P}<0.05)$ when compared to either control or steatotic groups respectively.

$\mathrm{I} / \mathrm{R}$ in steatotic group also produced significant increase in liver enzymes (ALT, AP and LDH) and MDA $(\mathrm{P}<0.05)$ when compared to $\mathrm{I} / \mathrm{R}$ in normal rats.

NAC administration during $\mathrm{I} / \mathrm{R}$ either in normal or steatotic rats produced significant reduction in liver enzymes (ALT, AP and LDH), TNF- $\alpha$ and MDA $(\mathrm{P}<0.05)$ and significant increase in reduced GSH and catalase enzyme $(\mathrm{P}<0.05)$ when compared to $\mathrm{I} / \mathrm{R}$ in either normal or steatotic groups respectively. 
Table (1): Mean and standard deviation of liver enzymes among studied groups.

\begin{tabular}{|c|c|c|c|c|c|c|c|c|}
\hline Grou & Control & $\mathbf{I} / \mathbf{R}$ & $\begin{array}{l}\text { NAC } \\
+ \text { I/R } \\
\text { IIIA }\end{array}$ & Steatosis & $\begin{array}{l}\text { Steatosis } \\
+ \text { I/R } \\
\text { IIB }\end{array}$ & $\begin{array}{l}\text { Steatosis } \\
+ \text { I/R } \\
+ \text { NAC } \\
\text { IIIB }\end{array}$ & $\mathbf{F}$ & Relations \\
\hline ALT u/l & $\begin{array}{r}26.35 \\
+5.51 \\
\end{array}$ & $\begin{array}{l}125.71 \\
+20 \\
\end{array}$ & $\begin{array}{r}48.42 \\
+4.43 \\
\end{array}$ & $\begin{array}{r}29.86 \\
+5.59 \\
\end{array}$ & $\begin{array}{r}172.49 \\
+22.92 \\
\end{array}$ & $\begin{array}{l}70.66 \\
+11.97 \\
\end{array}$ & 142.85 & \multirow{3}{*}{$\begin{array}{l}\text { IIA vs IA* } \\
\text { IIB vs IB* } \\
\text { IIB vs IIA* } \\
\text { IIIA vs IIA* } \\
\text { IIIB vs IIB* }\end{array}$} \\
\hline $\mathbf{A P} \mathbf{u} / \mathbf{l}$ & $\begin{array}{l}51.49 \\
+8.91 \\
\end{array}$ & $\begin{array}{l}97.48 \\
+11.94 \\
\end{array}$ & $\begin{array}{l}62.86 \\
\pm 10.66 \\
\end{array}$ & $\begin{array}{l}57.589 \\
+11.42 \\
\end{array}$ & $\begin{array}{r}210.86 \\
+24.86 \\
\end{array}$ & $\begin{array}{l}96.06 \\
+12.01 \\
\end{array}$ & 138.75 & \\
\hline LDH u/l & $\begin{array}{l}61.61 \\
+13.99 \\
\end{array}$ & $\begin{array}{l}94.60 \\
+13.13 \\
\end{array}$ & $\begin{array}{l}71.46 \\
+10.51 \\
\end{array}$ & $\begin{array}{l}65.70 \\
+12.83 \\
\end{array}$ & $\begin{array}{r}150.85 \\
+15.19 \\
\end{array}$ & $\begin{array}{r}100.99 \\
+14.49 \\
\end{array}$ & 12.01 & \\
\hline
\end{tabular}

* Significant $(\mathbf{P}<\mathbf{0 . 0 5})$.

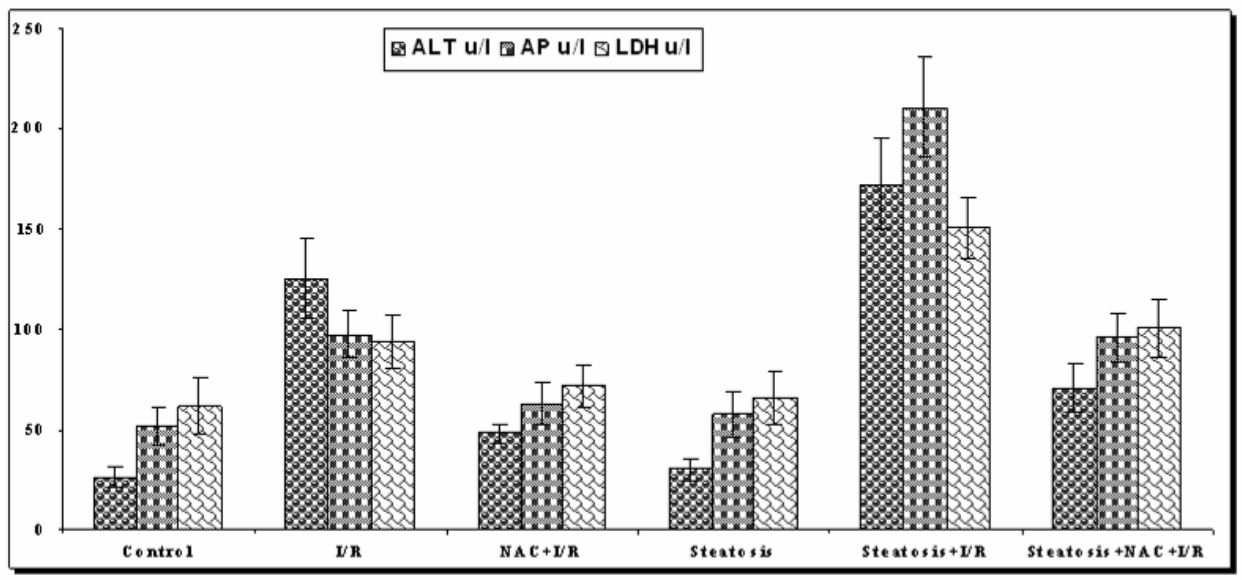

Fig. (1): Mean and standard deviation of liver enzymes among studied groups 
Table (2): Mean and standard deviation of TNF- $\alpha$, MDA, reduced GSH and catalase among studied groups.

\begin{tabular}{|c|c|c|c|c|c|c|c|c|}
\hline Group & Control & $\mathbf{I} / \mathbf{R}$ & $\begin{array}{l}\text { NAC } \\
+ \text { I/R } \\
\\
\text { IIIA }\end{array}$ & Steatosis & $\begin{array}{c}\text { Steatosis } \\
+\mathbf{I} / \mathbf{R} \\
\\
\text { IIB }\end{array}$ & $\begin{array}{c}\text { Steatosis } \\
+\mathbf{I} / \mathbf{R} \\
+ \text { NAC } \\
\text { IIIB }\end{array}$ & $\mathbf{F}$ & Relations \\
\hline TNF- $\alpha \mathrm{pg} / \mathrm{ml}$ & $\begin{array}{r}33.58 \\
+8.96\end{array}$ & $\begin{array}{r}90.73 \\
+8.37\end{array}$ & $\begin{array}{r}60.36 \\
+8.13\end{array}$ & $\begin{array}{r}54.59 \\
+8.96\end{array}$ & $\begin{array}{r}101.85 \\
+10.48\end{array}$ & $\begin{array}{r}101.85 \\
+10.78\end{array}$ & 56.80 & \multirow{4}{*}{$\begin{array}{l}\text { IA vs IB* } \\
\text { except in } \\
\text { catalase } \\
\text { IIA vs IA* } \\
\text { IIB vs IB* } \\
\text { IIB vs IIA* } \\
\text { only in } \\
\text { MDA } \\
\text { IIIA vs IIA* } \\
\text { IIIB vs IIB* }\end{array}$} \\
\hline $\begin{array}{l}\text { MDA } \\
\text { umol/ml }\end{array}$ & $\begin{array}{r}1.32 \\
+0.16\end{array}$ & $\begin{array}{c}1.91 \\
+0.09\end{array}$ & $\begin{array}{c}1.28 \\
+0.14\end{array}$ & $\begin{array}{r}1.62 \\
+0.27\end{array}$ & $\begin{array}{c}2.24 \\
+0.21\end{array}$ & $\begin{array}{c}1.57 \\
+0.15\end{array}$ & 34.21 & \\
\hline $\begin{array}{l}\text { reduced GSH } \\
\mathrm{nmol} / \mathrm{mg}\end{array}$ & $\begin{array}{r}8.70 \\
+0.57 \\
\end{array}$ & $\begin{array}{c}6.71 \\
+0.51 \\
\end{array}$ & $\begin{array}{r}8.88 \\
+0.75 \\
\end{array}$ & $\begin{array}{c}7.71 \\
+0.60 \\
\end{array}$ & $\begin{array}{r}6.54 \\
+0.43 \\
\end{array}$ & $\begin{array}{r}7.72 \\
+0.43 \\
\end{array}$ & 23.98 & \\
\hline Catalase u/gm & $\begin{array}{l}188.96 \\
+8.88\end{array}$ & $\begin{array}{l}164.71 \\
+7.70\end{array}$ & $\begin{array}{r}201.23 \\
+14.06\end{array}$ & $\begin{array}{l}177.66 \\
+8.77\end{array}$ & $\begin{array}{r}+157.73 \\
+10.88\end{array}$ & $\begin{array}{l}+187.61 \\
+12.66\end{array}$ & 18.37 & \\
\hline
\end{tabular}

* Significant $(\mathbf{P}<\mathbf{0 . 0 5})$.

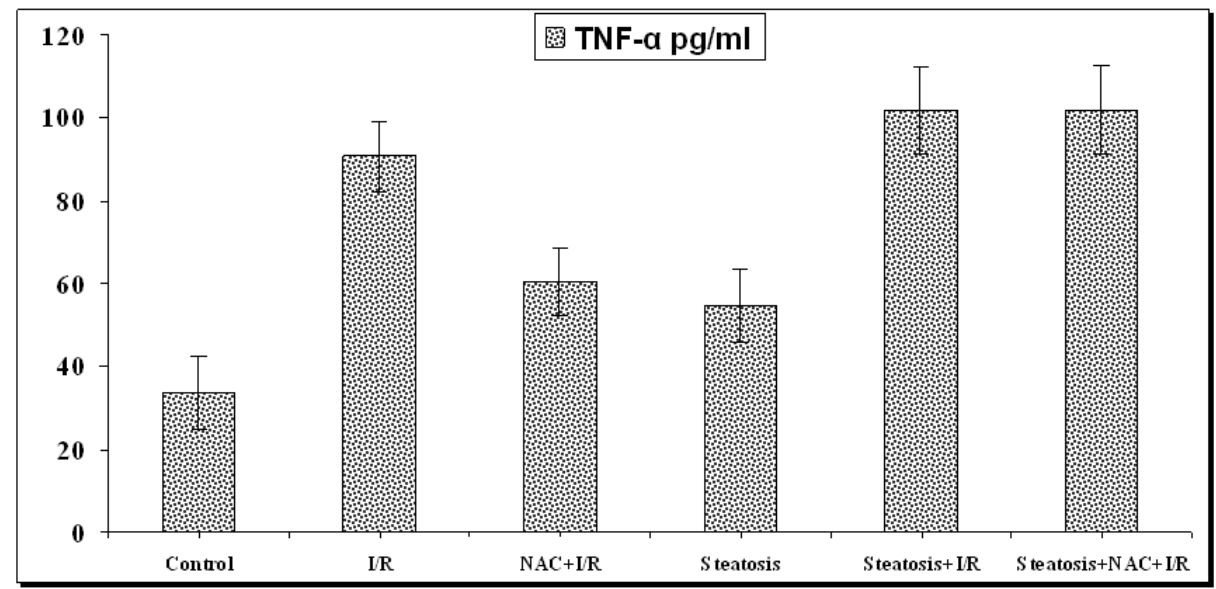

Fig. (2): Mean and standard deviation of TNF- $\alpha$ among studied groups 


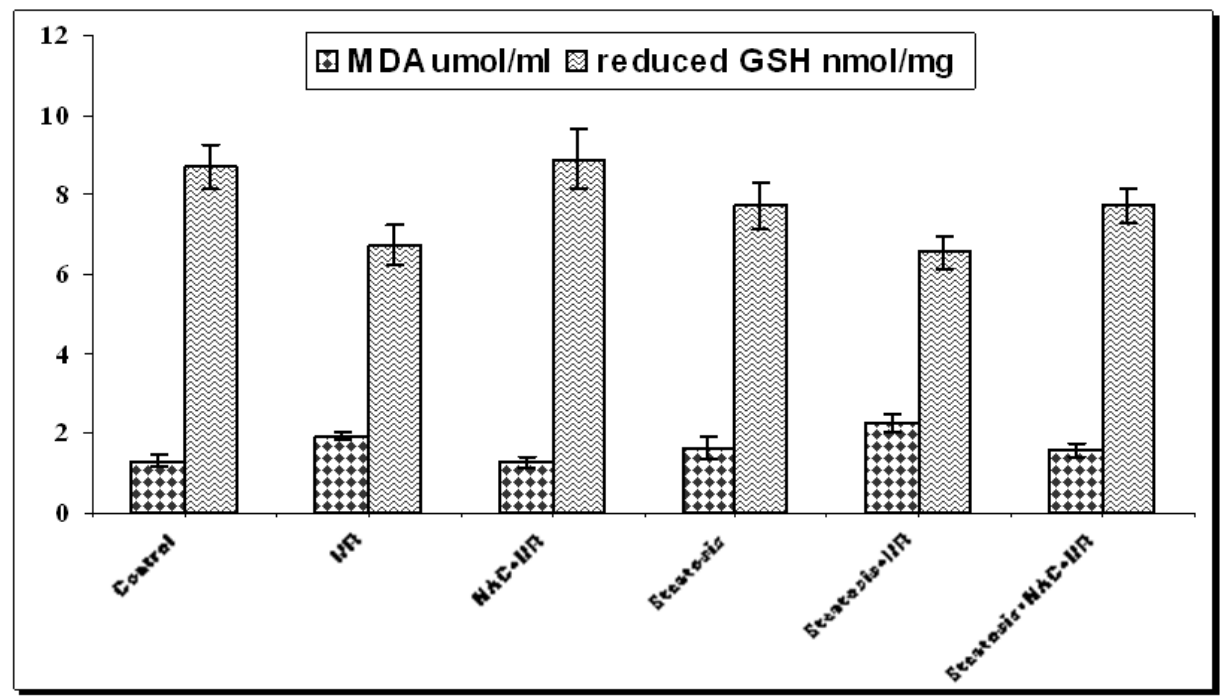

Fig. (3): Mean and standard deviation of MDA, reduced GSH among studied groups

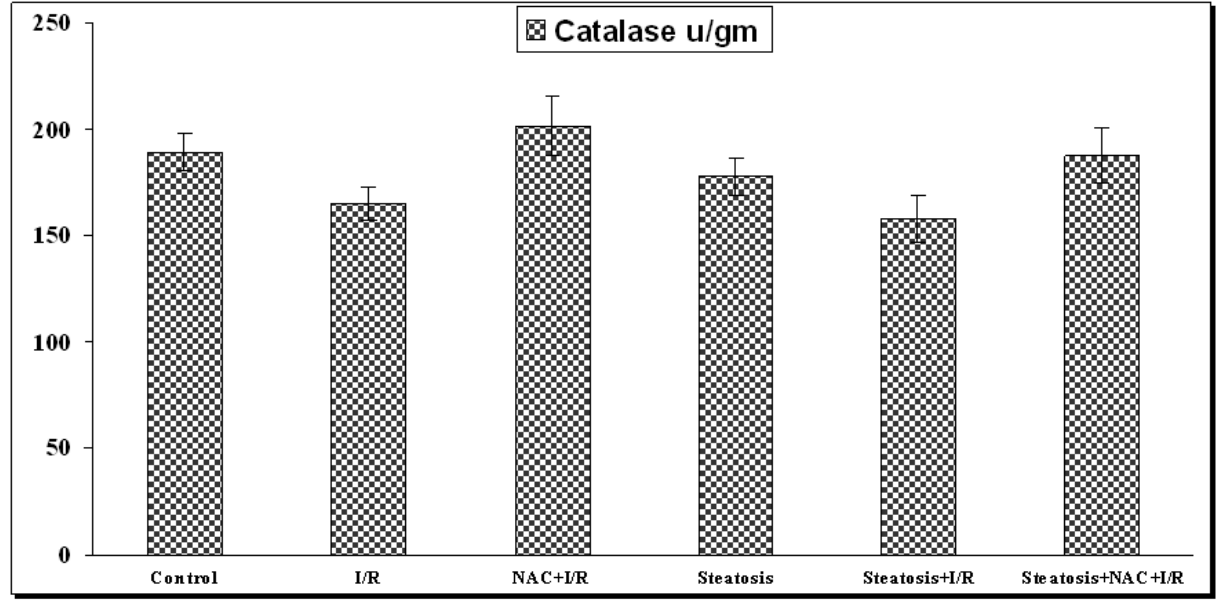

Fig. (4): Mean and standard deviation of Catalase among studied groups 


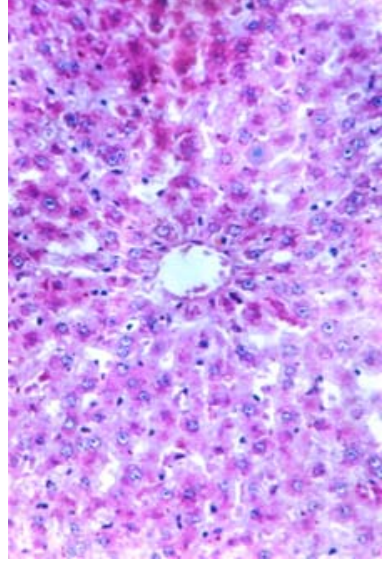

Fig. (5): Section in liver showing normal liver architecter. ( $\mathrm{H} \mathrm{x} \& \mathrm{E} \mathrm{x}$ 400)

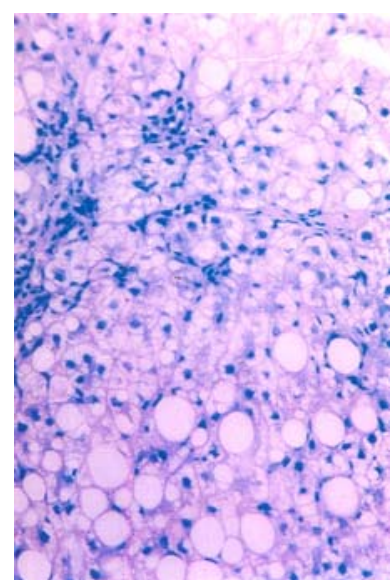

Fig. (6): Section in liver received high cholesterol diet showing extensive steatosis $(++++)$ with moderate inflammatory infiltration $(+++)$.

(H x \& E x 400)

\section{DISCUSSION}

The induction of hepatic steatosis in this study was accompanied by inflammation, lipid peroxidation and decreased level of intracellular free radical scavenger. This confirms the vulnerability and increased susceptibility of the steatotic livers to $\mathrm{I} / \mathrm{R}$ injury. So, hepatic inflammation and oxidative stress are already present in steatotic livers and aggravated in ischemic liver injury during reperfusion. These results are agreed by many authors ${ }^{(\mathbf{1 6}, \mathbf{1 7})}$.

Mitochondria are involved in fatty acid $\beta$ oxidation and oxidative phosphorylation. Additionally, these organelles are an important source of reactive oxygen species (ROS) and impairment of their activity plays a central role in steatotic liver damage $^{(\mathbf{1 6})}$. Mitochondrial-oxidation impairment leading to increased free fatty acids inside hepatocytes which increases the cell volume resulting in decreased sinusoidal space and impaired microcirculatory blood flow up to $50 \%$ in fatty liver ${ }^{(\mathbf{1 8})}$. At the same time, the free fatty acids inhibit acetyl coenzyme A, an important cofactor in krebs cycle and gluconeogenesis, thus leading to decreased production of adenosine triphosphate (ATP) ${ }^{(\mathbf{1 9})}$.

It is clear from our results that $I / R$ produced significant increase in inflammatory marker (TNF- $\alpha$ ) and oxidative stress (increased MDA and decreased reduced GSH and catalase) in both normal and steatotic rats in comparison to their control groups and still significant increase in steatotic $\mathrm{I} / \mathrm{R}$ when compared to $\mathrm{I} / \mathrm{R}$ in normal rats.

I/R causes mitochondrial dysfunction and increased activity of nicotinamide adenine dinucleotide phosphate (NADPH) leading to generation of reactive oxygen species (ROS) and reactive nitrogen species (RNS). Both can cause cellular injury 
through peroxidation of membrane lipids, protein denaturation and oxidative DNA damage ${ }^{(20)}$.

Reactive nitrogen species (RNS) like peroxynitrite is a highly reactive free radical formed by combination of nitric oxide (NO) with superoxide anions. Under normal conditions, this reaction is prevented by continuous removal of NO by haemoglobin. Nonetheless, during later stage of reperfusion, NO production increases as a result of the expression of inducible nitric oxide synthase (iNOS). Excessive NO production leads to formation of peroxynitrite which causes mitochondrial dysfunction, impaired circulation and hepatic injury ${ }^{(21)}$.

Nuclear factor kappa B (NFkappa B) is activated by oxidative stress during hepatic $\mathrm{I} / \mathrm{R}$ and may play a significant role in the induction of inducible nitric oxide synthase (iNOS) gene ${ }^{(22)}$. The humoral induction of inflammatory mediators such as cytokines and eichosanoids may also involved $^{(21)}$.

The sinusoidal microcirculatory impairment during reperfusion has been also implicated in the pathogenesis of liver damage and may be caused by sinusoidal vasoconstriction mediated by an altered endothelin-NO balance ${ }^{(23)}$, sinusoidal endothelial cell swelling with luminal narrowing ${ }^{(24)}$ and/or increased expression of adhesion molecules with subsequent leukocyte and endothelial cell interaction ${ }^{(25)}$.

Activation of toll-like receptor 2 and 4 gene may play an important role in the ROS-induced liver injury after I/R. Signaling by toll-like receptors occurs through activation of NF-kappa
$\mathrm{B}$ and $\mathrm{JNK} / \mathrm{SAPK}$ which is activated by ROS. ROS can also modify membrane components and is a known inducer of apoptosis and necrosis $^{(5)}$.

NAC succeeded to significantly reduce liver enzymes (ALT, AP and LDH), inflammation (TNF- $\alpha$ ) and lipid peroxidation (MDA) and also to significantly increase reduced GSH and catalase when administered during $\mathrm{I} / \mathrm{R}$ either in normal or steatotic rats.

NAC is a thiol-containing compound that directly interacts and detoxifies free radicals by non enzymatic reactions (free radical scavenger) ${ }^{(26)}$. It is also deacetylated to form cysteine which is the precursor of glutathione, one of the most important components of intracellular antioxidant system ${ }^{(27)}$. By its antioxidant action, it inhibits lipid peroxidation, it also potentiates $\gamma$ aminolevulinate dehydratase activity, an effect that is not related to hepatic peroxidation $^{(28)}$.

The anti-inflammatory effect of NAC may be related not only to inhibited expression of (iNOS), but it also blocks the upregulated NF-kappa B binding activity after liver reperfusion ${ }^{(22)}$. NAC also inhibits expression of intercellular adhesion molecule- 1 and vascular cell adhesion molecule-1 (ICAM-1 and VCAM-1) and causes shedding of selectins which might be contributing factors to decrease leukocyte adherence and improve microcirculatory haemodynamics ${ }^{(29)}$. It was also proven that NAC inhibits activation of tolllike receptor 2 and 4 mRNA and protein and the induction of TNF- $\alpha$ resulting from $I / R$ injury via 
modulating redox state. Thus, it may mitigate liver injury following $\mathrm{I} / \mathrm{R}$ in $\operatorname{mice}^{(5)}$.

NAC seems to attenuate hepatic $\mathrm{I} / \mathrm{R}$ injury through decreasing platelet activation, increasing cAMP in ischemic liver tissue, and decreasing the activity of glutathione-Stransferase ${ }^{(30)}$.

The antifibrotic role was also stated via inhibition of stellate cell activation $^{(31)}$ and inhibition of profibrotic cytokine, liver transforming growth factor-beta (TGF-beta) ${ }^{(\mathbf{3 2})}$.

Many authors proved the antiapoptic effect of NAC through inhibiting the cell cycle arrest at the $\mathrm{S}$ and $\mathrm{G} 2 / \mathrm{M}$ phase and shifting the cells to G1 phase thus decreasing the degree of DNA damage and increasing the cell viability ${ }^{(33,34)}$.

The antisteatotic effect of NAC has bean suggested through two mechanisms. First, that NAC replenishes the mitochondrial GSH pool and restores the mitochondrial function and enhances regeneration of ATP, thus leading to reduced ROS generation $^{(35)}$. Second, that NAC may minimize damage to circulation in liver, thus reducing haemorrhage in ischemic livers ${ }^{(4)}$.

\section{CONCLUSION}

NAC prevents liver tissue damage and may be considered as a promising therapeutic candidate for chemoprevention of $\mathrm{I} / \mathrm{R}$ injury through antioxidant, antiinflammatory, antifibrotic, antiapoptic and antisteatotic effects either in normal or steatotic livers. Thus, it may have a role in increasing the cell viability, preventing the early graft rejection and increasing survival rate during liver surgery and transplantation.

\section{ACKNOWLEDGEMENT}

Great thanks for Karima ElDesuky, Professor of Histopathology for her help in histological part of the work.

\section{REFERENCES}

1. Bhogal R.H., Curbishley S.M., Weston C.J., Adams D.H. and Afford S.C.: Reactive oxygen species mediate human hepatocyte injury during hypoxia/reoxygenation. Liver Transpl. 2010, 16(11): 1303-10.

2. Hoffmann K., Büchler M.W. and Schemmer P.: Supplementation of amino acids to prevent reperfusion injury after liver surgery and transplantation-where do we stand today? Clin Nutr. 2010;30(2):143-7.

3. Fusai G., Glantzounis G.K., Hafez t., Yang W., Quaglia A. and Sheth H.: N-Acetylcysteine ameliorates the late phase of liver ischemia/reperfusion injury in the rabbit with hepatic steatosis. Clinical Science. 2005; 109: 46573.

4. Glantzounis G.K., Yang W., Koti R.S., Mikhailidis D.P., Seifalion A.M. and Davidson B.R.: Continuous infusion of Nacetylcyteine reduces liver warm ischemia-reperfusion injury. British Journal of Surgery. 2004; 91: 1330-9.

5. Jin X., Wang L., Wu H., Zhang L., Wang C., Tian Y. and Zhang J.: N-acetylcysteine inhibits 
activation of toll-like receptor 2 and 4 gene expression in liver and lung after partial hepatic ischemia-reperfusion injury in mice. Hepatobiliar, Pancreat Dis Int. 2007; 6(3): 284-9.

6. Schauer R.J., Gerrbes A.L., Vonier D., Meissner H., Micw P. and Leiderer R.: Glutathione protects the rat liver against reperfusion injury after prolonged warm ischemia. Ann Surg 2004; 239: 220-31.

7. Browning J.D., Szczepaniak L.S., Dobbins R., Nuremberg P., Horton J.D. and Cohen J.C. : Prevalance of hepatic steatosis in an urban population in the united states: impact of ethnicity. Hepatology. 2004; 40: 1387-95.

8. Feldstein A.E., Wernbwrg N.W., Canbay A., Guicciardi M.E., Bronk S.F. and Rydzewski R.: Free fatty acids promote hepatic lipotoxicity by stimulating TNFalpha expression via a lysosomal pathway. Hepatology. 2004; 40: 185-94.

9. Schmidt E. and Schmidt F.W.: Colorimetric method for determination of alanine aminotransferase enzyme. Biol Clin. 1963; 3: P1.

10. Rec GSCC.: Determination of alkaline phosphatase enzyme. J Clin Chem Clin Biochem. 1972, 10-18.

11. King J.: The dehydrogenase or oxi-reductase lactate dehydrognase In: Practical Clinical Enzymology (London): Van No Strand. 1965:106.

12. Rajadura M.: Comparative effect of Aegle marmelos extract and alpha tocopherol on serum lipids, lipid peroxidation and cardiac enzyme in rats with isoproterenol-induced myocardial infarction. Sin Med J. 2005; 46(2): 78-81.

13. Buege J.A. and Aust S.D.: Microsomal lipid peroxidation. Packer L. (ed.), Methods in enzymology. New York Academic, 1978; 52: 302-10.

14. Hissin P.J. and Hifi R.: A fluorometric method for interrelation between vitamine $\mathrm{E}$ and polyunsaturated fatty acids in adult men. Vitam. Horm. 1979; 20: 541-58.

15. Goldber M. and Ramdath D.: Glutathione. In: Methods of Enzymatic Analysis. Ergmeye, H.V. $3^{\text {rd }}$ ed., Verbeg, 1983.

16. Formenty B. and Pessayre D.: Inhibition of mitochondrial betaoxidation as a mechanism of hepatotoxcity. Pharmacol Ther. 1995; 67: 101-54.

17. Vetelainen $R$., Van vliet A., Gouma D.J. and Gulik T.M.: Steatosis as a risk factor in liver surgery. Ann Surgery. 2007; 245: 20-30.

18. Ijaz S., Yang W., Winslet M.C. and Seiflian A.M.: Impairment of hepatic microcirculation in fatty liver. Microcirculation. 2003; 10: 447-56.

19. Sun C.K., Zhang X.Y., Zimmermann A., Davis G. and Wheatley A.M.: Effect of ischemia-reperfusion injury on the microcirculation of the steatotic liver of the zucker rats. Transplantation. 2001; 72: 162531.

20. Jaeschke H.: Reactive oxygen and mechanisms of inflammatory 
liver injury. J Gastroenterol Hepatol. 2000; 15: 718-24.

21. Andraus W., Souza G.F.P., Oliveira M.G., Haddad L.B.P., Coelho A.M.M. and Galvao R.M.C.: S-nitroso-Nacetylcysteine ameliorates ischemia reperfusion injury in the steatotic liver. Clinics. 2010; 65(7): 715-21.

22. Hur G.M., Ryu Y.S., Yun H.Y., Jeon B.H., Kim Y.M., Seok J.H. and Lee J.H.: Hepatic ischemiareperfusion in rats induces iNOS gene transcription by activation of NF-kappa $\beta$. Biochem Biophys Res Commun. 1999; 261(3): 91722.

23. Uhlmann D., Uhlmann S. and Spiegel H.U.: Endothelin/nitric oxide balance influences hepatic ischemia-reperfusion injury. $\mathrm{J}$ Cardiorasc Pharmacol. 2000; 36(Suppl. 1): 5212-14.

24. Lentsch A.B., Kato A., Yoshidome H., Mc Masters K.M. and Edwards M.J.: Inflammatory mechanisms and therapeutic sterategies for warm hepatic ischemia/reperfusion injury. Hepatology. 2000; 32: 169-73.

25. Jaeschke H., Farhood A. and Smith C.W.: Neutrophils contribute to ischemia/reperfusion injury in rat liver in vivo. FASEB J. 1990; 4: 3355-59.

26. Chyka P.A., Butler A.Y., Holliman B.J. and Herman M.I.: Utility of acetylcysteine in treating poisonings and adverse drug reactions. Drug Saf. 2000; 22: 133-48.

27. Haliwell B. and Gutteridge J.M.C.: Free radicals in biology and medicine. Oxford University Press: Oxford. 1999; 840-2.

28. Brandao R. and Nogueira C.W.: Inhibiton of $\gamma$-aminolevulinate dehydratase activity induced by mercuric chloride is potentiated by $\mathrm{N}$-acetylcysteine in vitro. Food Chem. Toxicol. 2011; 49(1): 3058.

29. Taut F.J., Schmidt H., Zapletal C.M., Thies J.C., grube C., Motsch J., Klar E. and Martin E.: N-acetylcysteine induces shedding of selectins from liver and intestine during orthotopic liver transplantation. Clin Exp Immunol. 2001; 124(2): 337-41.

30. Smyrniotis V., Arkadopoulos N., Kostopanagiotou G., Thodoropoulos t., Thodoraki K., Farantos C., Kairi E. and Paphiti A.: Attenuation of ischemic injury by Nacetylcysteine preconditioning of the liver. J Surg Res. 2005; 129(1): 31-7.

31. Shinkawa H., Takemura S., Minamiyama Y., Kodai S., Tsukioka T., Osada-Oka M., Kubo S., Okada S. and Suehiro S.: S-allylcysteine is effective as a chemopreventive agent against porcine serum-induced hepatic fibrosis in rats. Oskada City Med J. 2009; 55(2): 61-9.

32. Galicia-Moreno M., RodriguezRivera A., Reyes-Gorditlo K., Segovia J., Shibayama M. and Tsutsumi V.: N-acetylcysteine prevents carbon tetrachlorideinduced liver cirrhosis: role of liver transforming growth factorbeta and oxidative stress. Eur $\mathrm{J}$ Gastroentrol Hepatol. 2009; 21(8): 908-14. 
33. North T.E., Babw I.R., Vedder L.M., Lord A.M., Wishnok J.S., Tannenbaum S.R., Zon L.I. and Goessling W.: PGE2regulated wnt signaling and $\mathrm{N}$ acetylcysteine are synergistically hepatoprotective in zebra fish acetaminophen injury. Proc Natl Acad Su USA. 2010; 107(40): 17315-20.

34. Odewumi C.O., Badisa V.L., Le U.T., Latinwo L.M., Ikediobi C.O., Badisa R.B. and Darling-
Reed S.F.: Protective effect of Nacetylcyteine against cadmiuminduced damage in cultured rat normal liver. Int $\mathrm{J}$ Mol Med. 2011; 27(2): 243-8.

35. Chen Y., Johansson E., Yang Y., Miller M.L., Shen D., Drlicky D.J. and Shertzer H.G.: Oral Nacetylcysteine rescues lethality of hepatocyte-specific Gclcknockout mice, providing a model for hepatic cirrhosis. J Hepatol. 2010; 53(6): 1085-94.

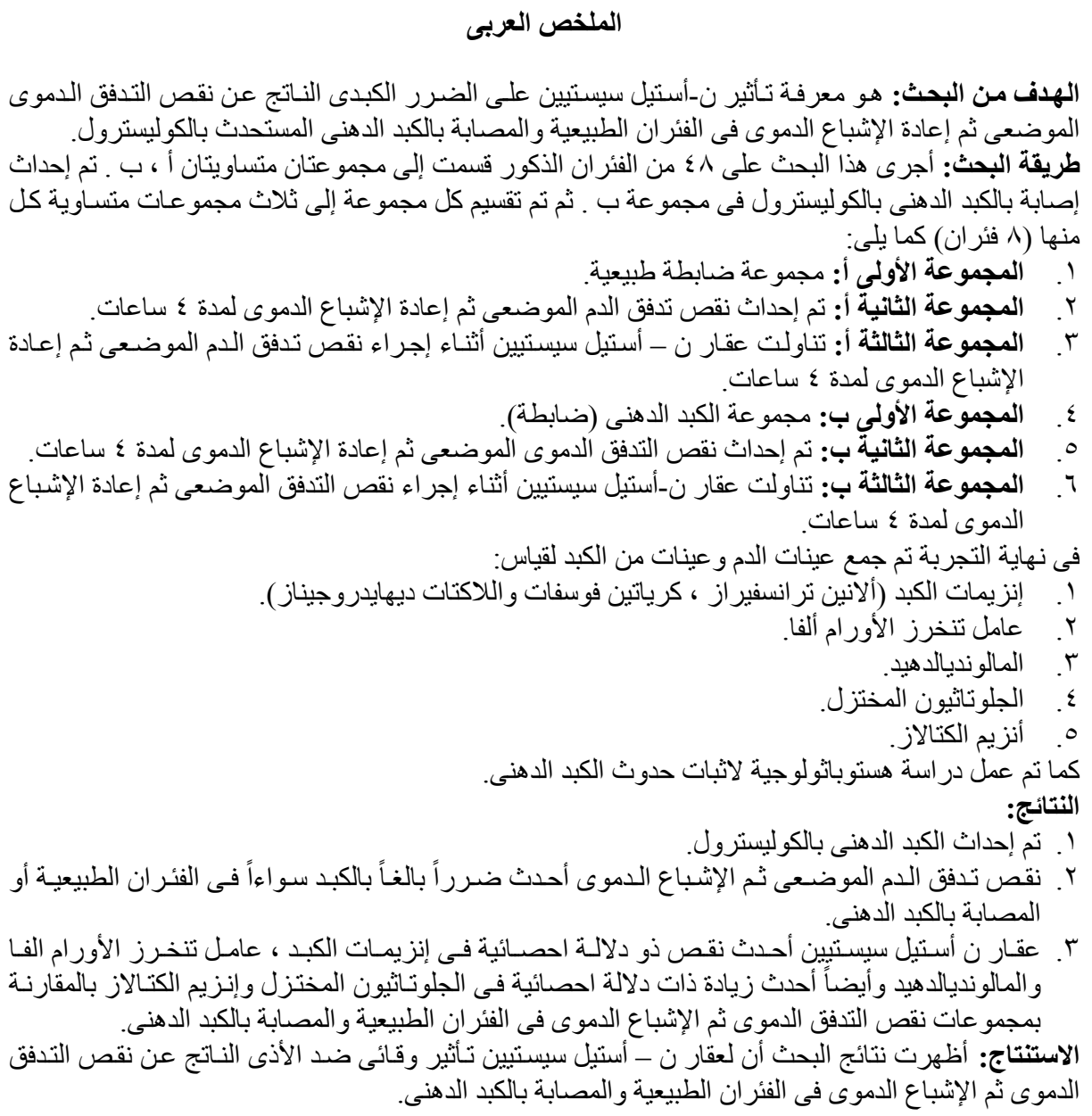

